\title{
Aplikasi Diagnosa Gejala Demam Pada Balita Menggunakan Metode Certainty Factor (CF) dan Jaringan Syaraf Tiruan (JST)
}

\author{
Septya Maharani ${ }^{\mathrm{a},{ }^{*}}$, Kusworo Adi ${ }^{\mathrm{b}}$ \\ ${ }^{a}$ Jurusan Ilmu Komputer, Fakultas MIPA, Universitas Mulawarman \\ ${ }^{\mathrm{b} J u r u s a n}$ Fisika, Fakultas Sains dan Matematika, Universitas Diponegoro
}

Naskah Diterima : 10 Januari 2013; Diterima Publikasi : 30 Maret 2013

\begin{abstract}
Symptoms of fever of toddlers have a devastating effect if too late to get treatment is not appropriate, to make it easier for parents to detect the type of disease, it is necessary to build an expert system application detection of disease symptoms of fever in children for early detection of disease. Knowledge base is implemented as a basis for expert system applications by using a combination of certainty factors (certainty factor) and ANN (artificial neural networks). Methods This study is a combination of $\mathrm{CF}$ as $\mathrm{CF}$ is the rule and the results will form a pattern which is a merger of the ANN clinical parameter that indicates the amount of trust as the knowledge base of disease diagnosis of fever in children 10 to 40 symptoms, the system uses a total of 40 symptoms as a medic training data with records of 20 patients. From the results of such testing, the application has been concluded at $86.67 \%$ accuracy rate.
\end{abstract}

Keywords: Fever; Expert systems; Certainty Factor; Neural networks

\begin{abstract}
Abstrak
Gejala demam terhadap balita memiliki dampak buruk apabila terlambat mendapatkan penanganan yang kurang tepat, untuk memudahkan para orang tua mendeteksi jenis penyakit yang diderita, untuk itu perlu dibangun sebuah aplikasi sistem pakar deteksi penyakit gejala demam pada anak untuk mendapatkan deteksi awal penyakit. Basis pengetahuan diimplementasikan sebagai dasar aplikasi sistem pakar dengan menggunakan kombinasi metode faktor kepastian (certainty factor) dan JST (jaringan Syaraf Tiruan). Penelitian ini merupakan Kombinasi Metode CF sebagai rule dan hasil CF tersebut akan membentuk pola JST yang merupakan penggabungan nilai parameter klinis yang menunjukkan besarnya kepercayaan sebagai basis pengetahuan diagnosa 10 penyakit demam pada anak dengan 40 gejala, Sistem ini menggunakan sebanyak 40 gejala sebagai data pelatihan dengan rekam medic dari 30 pasien. Dari hasil pengujian tersebut, aplikasi telah menyimpulkan tingkat keakuratan sebesar $86,67 \%$.
\end{abstract}

Kata kunci : Demam; Sistem pakar; Certainty Factor; Jaringan Syaraf Tiruan

\section{Pendahuluan}

Demam merupakan respon terhadap tubuh disebabkan adanya keadaaan masuknya mikroorganisme dapat berupa virus, bakteri, parasit, maupun jamur yang disebut infeksi. Demam juga menimbulkan kecemasan, fobia, dan stress tersendiri bagi orangtua, sehingga orang tua mempertimbangkan untuk menghubungi atau mengunjungi dokter jika telah menemukan gejalagejala penyakit pada balita. Penyelesaian permasalahan ini dapat dipermudah dengan membangunan aplikasi kombinasi Certainty Factor (CF) dan Jaringan Syaraf Tiruan (JST) yang merupakan sistem untuk memudahkan para orang tua mendeteksi gejala dini pada balita, sehingga orang

*) Penulis korespondensi : septyamaharani@yahoo.com tua dengan mudah melakukan tindakan penanganan awal sebelum melakukan pemeriksaan ke dokter. Agar mendapatkan hasil yang diinginkan, peneliti menggunakan kombinasi metode $\mathrm{CF}$ yang memiliki metode tersendiri, dimana metode tersebut dapat diimplementasikan pada sistem permasalahan apapun khususnya pada sistem pakar dan JST yang merupakan bagian dari ilmu kecerdasan buatan yang berhubungan dengan pengenalan pola, dimana semua keluaran atau kesimpulan yang ditarik oleh jaringan didasarkan pada pengalamannya selama mengikuti proses pelatihan, sehingga semakin banyak data yang didapat dan pelatihan yang dilakukan, semakin mendekati hasil yang diharapkan. 


\section{Kerangka Teori}

\subsection{Demam}

Demam terjadi jika berbagai proses infeksi dan noninfeksi berinteraksi dengan mekanisme pertahanan hospes. Pada kebanyakan anak demam disebakan oleh agen mikrobiologi yang dapat dikenali dan demam menghilang sesudah masa yang pendek. Demam bukan penyakit, tetapi merupakan pertanda adanya penyakit atau benda asing dalam darah. Secara demikian sebenarnya adanya demam cukup bermanfaat, karena dengan adanya demam orang menjadi tersadar adanya sesuatu yang salah dalam dirinya. Demam ringan (sekitar $38{ }^{\circ} \mathrm{C}$ ) umumnya merupakan mekanisme pertahanan tubuh dan tidak berbahaya, namun demam yang tinggi dapat merupakan tanda bahaya dan bahkan pada hiperpireksia dapat menyebabkan timbulnya beberapa komplikasi akibat kekacauan dalam sistem tubuh. Demam lama atau berulang dapat terjadi akibat infeksi kronis seperti Tuberkulosis (TBC) atau merupakan pertanda adanya penyakit lainnya, seperti penyakit sendi, keradangan jaringan ikat, atau gangguan metabolisme.

Secara umum, jika demam segera membaik dengan pemberian obat penurun demam dan sakit tidak berlanjut lebih dari dua hari, maka pemberian obat tersebut sudah memadai. Apabila sakit berlanjut, hubungi dokter. Ungkapan ini sangat tepat, karena demam yang berlanjut lebih dari dua hari harus diamati kemungkinan penyebabnya. Konsultasi ke dokter adalah tindakan yang bijaksana.

Pada sub bab ini merupakan penjelasan mengenai macam-macam gangguan kesehatan yang dapat didiagnosa oleh sistem pakar ini.

\subsection{Certainty Factor}

Kemampuan sistem pakar yang memiki kemampuan bekerja dalam ketidakpastian, sehingga mampu memberikan penyelesaian dalam pengambilan keputusan. Sejumlah teori telah ditemukan untuk menyelesaikan ketidakpastian, termasuk diantaranya probabilitas klasik (classical probability), probabilitas Bayes (Bayesian probability), teori Hartley berdasarkan himpunan klasik (Hartley theory based on classical sets), teori Shannon berdasarkan pada probabilitas (Shanon theory based on probability), teori Dempster-Shafer (Dempster-Shafer theory), teori fuzzy Zadeh (Zadeh's fuzzy theory) dan faktor kepastian $(C F) . \mathrm{CF}$ diperkenalkan oleh Shortliffe Buchanan dalam pembuatan MYCIN. CF merupakan nilai parameter klinis yang diberikan MYCIN untuk menunjukkan besarnya kepercayaan. CF didefinisikan sebagai pada persamaan berikut:

$$
C F(H, E)=M B(H, E)-M D(H, E) .
$$

Kriteria:
- $\mathrm{CF}(\mathrm{H}, \mathrm{E})$ : $\mathrm{CF}$ dari hipotesis $\mathrm{H}$ yang dipengaruhi oleh gejala (evidence) E. Besarnya CF berkisar antara -1 sampai dengan 1 . Nilai -1 menunjukkan ketidakpercayaan mutlak sedangkan nilai 1 menunjukkan kerpercayaan mutlak.

- MB(H,E) : ukuran kenaikan kepercayaan (measure of increased belief) terhadap hipotesis $\mathrm{H}$ yang dipengaruhi oleh gejala $\mathrm{E}$.

- $\mathrm{MD}(\mathrm{H}, \mathrm{E})$ : ukuran kenaikan ketidakpercayaan (measure of increased disbelief) terhadap hipotesis $\mathrm{H}$ yang dipengaruhi oleh gejala $\mathrm{E}$.

\subsection{Jaringan Syaraf Tiruan}

Jaringan syaraf tiruan (JST) merupakan sistem yang mampu melakukan pengolahan informasi dengan memiliki kesamaan berpikir serta jaringan syaraf biologi manusia. JST tersebut akan dibentuk dengan menggunakan model matematika. JST dibentuk sebagai generalisasi model matematika dari jaringan syaraf biologi dengan asumsi.

Satu sel syaraf terdiri dari tiga bagian, yaitu: fungsi penjumlah (summing function), fungsi aktivasi (activation function), dan keluaran (output).

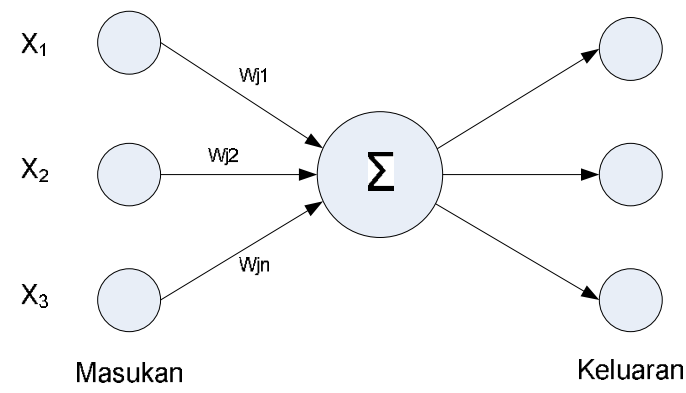

Gambar 1 Model Neuron (Hermawan, 2006)

Pada Gambar 1, neuron buatan diatas mirip dengan sel neuron biologis. Informasi (masukan) dikirim ke neuron dengan bobot tertentu. Masukan ini akan diproses oleh suatu fungsi yang akan menjumlahkan nilai-nilai bobot yang ada. Hasil dari penjumlahan kemudian akan dibandingkan dengan suatu nilai ambang (threshold) tertentu melalui fungsi aktivasi setiap neuron.

Model jaringan Backpropagation merupakan salah satu metode yang sangat baik dalam menangani masalah pengenalan pola-pola kompleks. Di dalam jaringan backpropagation, setiap unit yang berada di lapisan input terhubung dengan setiap unit yang ada di lapisan tersembunyi. Setiap unit yang ada di lapisan tersembunyi terhubung dengan setiap unit yang ada di lapisan output. Jaringan ini terdiri dari banyak lapisan (multilayer network).

Ketika jaringan diberikan pola masukan sebagai pola pelatihan, maka pola tersebut menuju unit-unit lapisan tersembunyi untuk selanjutnya diteruskan pada unit-unit di lapisan keluaran. Kemudian unitunit lapisan keluaran akan memberikan respon sebagai keluaran JST. Saat hasil keluaran tidak sesuai 
dengan yang diharapkan, maka keluaran akan disebarkan mundur (backward) pada lapisan tersembunyi kemudian dari lapisan tersembunyi menuju lapisan masukan.

Tahap pelatihan ini merupakan langkah proses melakukan pelatihan suatu JST, dengan melakukan perubahan bobot. Sedangkan penyelesaian masalah akan dilakukan jika proses pelatihan tersebut telah selesai, fase ini disebut fase pengujian.

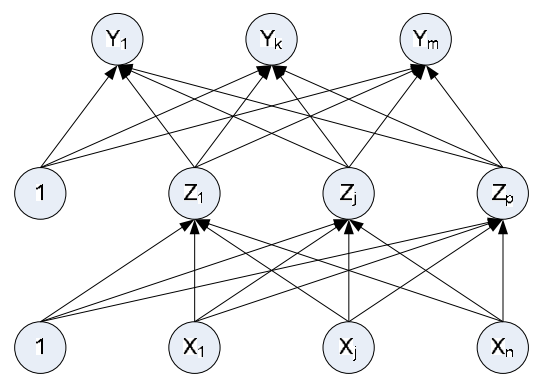

Gambar 2. Arsitektur Backpropagation (Siang, 2004)

\section{Metodologi}

Populasi dalam penelitian ini adalah gejala dari setiap penyakit pada dimana dari penelitian ini mengambil 10 penyakit dengan jumlah keseluruhan gejala adalah 40 gejala yang berasal dari hasil studi literature dan wawancara terhadap pakar.

Sampel penelitian yang akan digunakan untuk menguji keakuratan aplikasi dalam penerapan kombinasi dua metode Certainty Factor dan JST berupa data rekam medis pasien balita tahun 2011 dengan jumlah 30 pasien.

Model Siklus hidup yang telah berhasil diterapkan pada sejumlah proyek pengembangan sistem pakar adalah model linier, seperti 3 siklus ini terdiri dari sejumlah tahap mulai dari perencanaan (planning) hingga evaluasi sistem (sistem evaluation), dan akan berulang hingga sistem diimplementasikan, yang kemudian sistem akan memasuki tahap pemeliharaan dan evaluasi. Walaupun tidak digambarkan secara eksplisit, proses verifikasi dan validasi dijalankan secara pararel disetiap tahap. Masing-masing tahapan terdiri dari beberapa tugas (Task). Tidak semua task suatu tahap perlu dilaksanakan, bergantung pada tipe aplikasi yang dibangun.

Melalui proses akuisi pengetahuan ini, disimpulkan data yang diperoleh yaitu 10 jenis penyakit dan 40 gejala yang menyertainya. Aturan untuk menarik kesimpulan dibuat berdasarkan data yang diperoleh dan mengarahkan pengguna untuk memecahkan masalah. Data jenis penyakit yang diperoleh dapat dilihat pada Tabel 1 berikut :
Tabel 1. Daftar nama penyakit

\begin{tabular}{ccc}
\hline No & Kode penyakit & Nama Penyakit \\
\hline 1 & D01 & Difteri \\
2 & D02 & Parotitis \\
3 & D03 & Campak \\
4 & D04 & Cacar Air \\
5 & D05 & Faringitis \\
6 & D06 & DBD \\
7 & D07 & Tifoid \\
8 & D08 & Meningitis \\
9 & D09 & Influenza \\
10 & D10 & Kawasaki \\
\hline
\end{tabular}

Sumber :Data olahan dari primer

\subsection{Diagram Keputusan.}

Diagram keputusan digunakan untuk mempermudah menggambarkan aturan yang ada dalam sistem. Diagram keputusan pada sistem pakar ini digambarkan dalam Gambar 3.

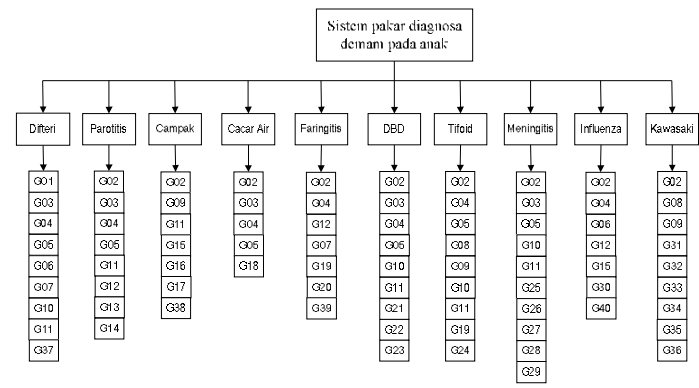

Gambar 3. Diagram keputusan pada sistem pakar

\subsection{Perancangan GUI}

Sebelum menggunakan aplikasi ini, akan dirancang tampilan awal pembuka yang dilengkapi oleh beberapa tools pendukung dalam penelitian tentang penggunaan kombinasi dua metode.

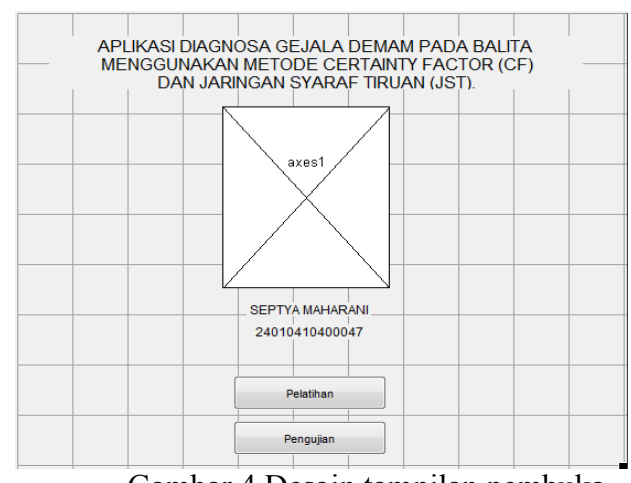

Keterangan :

a. Menu Pelatihan JST berisi from pelatihan JST, yang terdiri dari struktur JST, data Training, Patameter training $A N N$ serta hasil pelatihan.

b. Menu Pengujian JST berisi from pengujian JST, yang terdiri dari struktur JST uji dan MSE. 
Desain form pelatihan merupakan sub sistem dari form pembuka pada Gambar 5 Pada form ini akan disediakan beberapa tools sebagai syarat penggunan JST dalam melakukan pelatihan data latih.

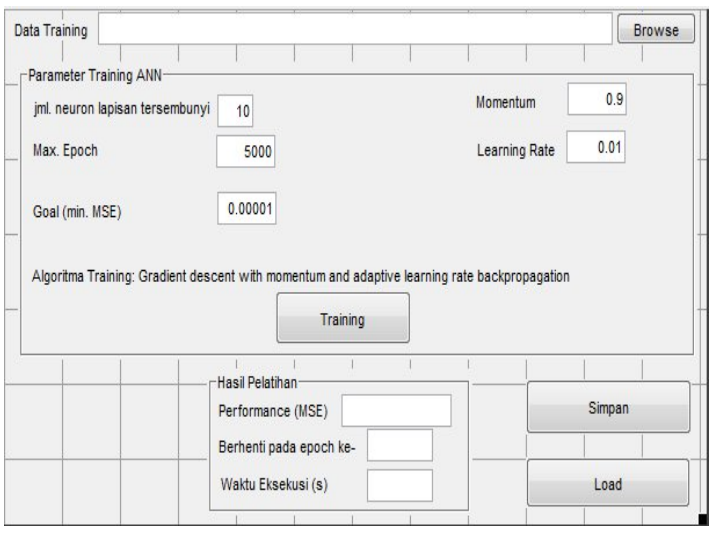

Gambar 5. Desain tampilan pelatihan

\section{Hasil dan Pembahasan}

Pada saat pengguna akan memilih tombol "pengujian" pada menu Utama, maka akan tampil menu pengujian, dimana pengguna dapat memasukan data uji dengan memilih tombol beberapa gejala yang dilengkapi dengan pernyataan ' $Y a$ ' dengan nilai 1 dan 'tidak' dengan nilai 0. Setelah memasukan data uji, pengguna dapat memilih tombol "Diagnosis" sehingga akan menampilkan tampilan pada Gambar 6 dibawah ini.

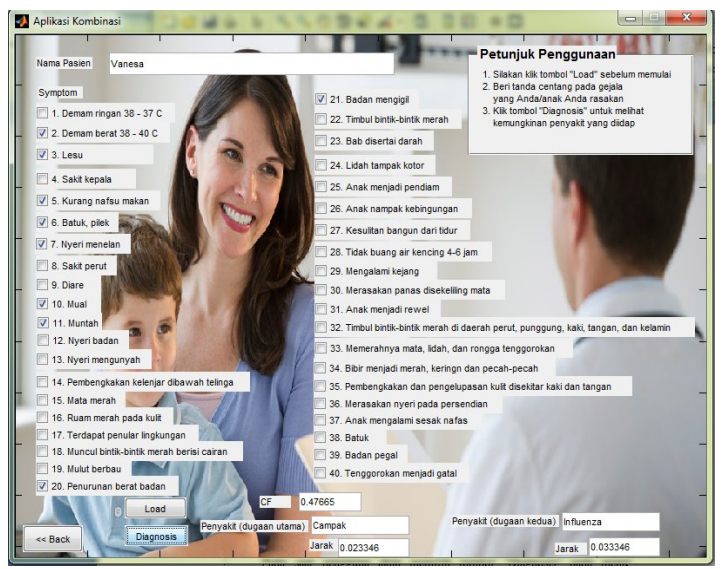

Gambar 6. Tampilan hasil pengujian

Pada saat pengguna akan memilih tombol "Diagnosis" pada menu Utama, maka akan tampil menu pengujian seperti pada Gambar 6, dimana pengguna dapat mengetahui penyakit dugaan dini yang terbagi menjadi dua yaitu penyakit dugaan utama dan penyakit dugaan kedua.
Pada tampilan grafik yang menunjukan Output jaringan dan target dianalisis telah disajikan pada Gambar 7.

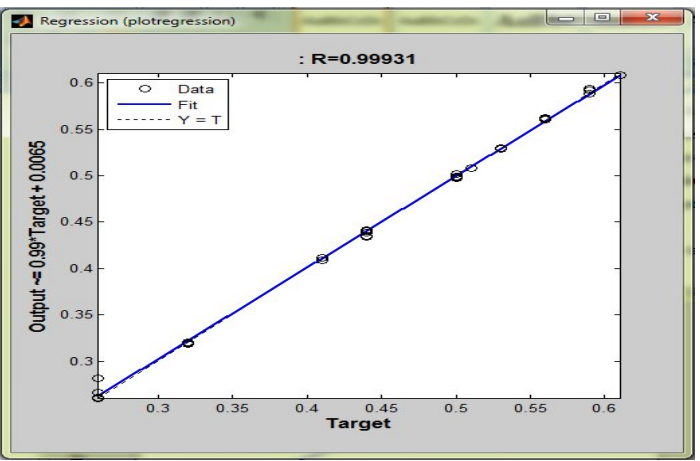

Gambar 7. Output jaringan

Hasil pelatihan sampai 4000 epoch menunjukan korelasi bernilai 0.99927 (hampir mendekati angka 1), menunjukan hasil yang baik untuk kecocokan output jaringan dengan target.

Untuk melihat perbandingan antara target dengan output jaringan, dapat disimak pada Gambar 8 yang berupa output jaringan (o) dan target (*) sebagian besar sudah berdekatan (hampir menempati posisi yang sama). Hasil terbaik terjadi apabila posisi (o) dan (*) benar-benar berada pada posisi yang sama.

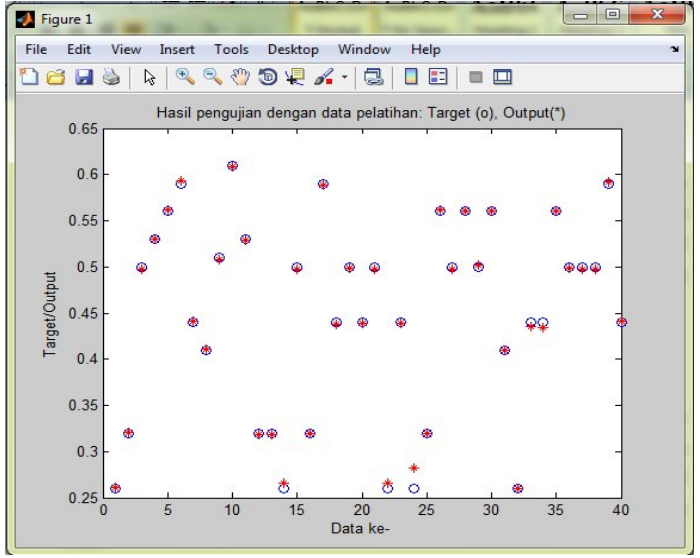

Gambar 8. Outputan jaringan

Proses pengujian akan dilakukan jika nilai target dan error mendekati nilai yang diinginkan. Pentingnya pengujian untuk mengetahui tingkat akurasi sistem ini terhadap penyakit demam, dengan memberikan inputan berupa data rekam medik pasien. 


\begin{tabular}{|c|c|c|c|c|c|c|c|}
\hline No & $\begin{array}{l}\text { Nama } \\
\text { Pasien }\end{array}$ & Nilai $\mathrm{CF}$ & $\begin{array}{c}\text { Penyalkit } \\
\text { utams } \\
\text { (PU) }\end{array}$ & Jarak pU & $\begin{array}{l}\text { Penyakit } \\
\text { dugagn } \\
\text { (PD) }\end{array}$ & Jaralk PD & Targe \\
\hline 1 & LS & 0.58537 & DBD & 0.0046282 & Kawasalki & 0.024628 & Tidal \\
\hline 2 & MR & 0.26796 & Differi & 0.0079588 & Parotitis & 0.052041 & Tidals \\
\hline 3 & SY & 0.31898 & Parotitis & 0.0010208 & Difteri & 0.058979 & Sesus \\
\hline 4 & AJ & 0.26615 & Difteri & 0.0026618 & Parotitis & 0.012662 & \\
\hline 5 & MA & 0.49734 & Campak & 0.0026618 & Influenza & 0.012662 & Sesua \\
\hline 6 & RA & 0.31913 & Parotitis & 0.00087167 & Difteri & 0.059128 & Sesua \\
\hline 7 & $\mathrm{AZ}$ & 0.58872 & Campal: & 0.0012821 & Kawasali & 0.021282 & \\
\hline 8 & RT & 0.4383 & Tifoid & 0.0016989 & Meningitis & 0.028301 & $\mathrm{Se}$ \\
\hline 9 & MAG & 0.49895 & Compak & 0.0010463 & Influenza & 0.011046 & \\
\hline 10 & $\mathrm{ZA}$ & 0.43871 & Tifoid & 0.001293 & Meningitis & 0.028707 & 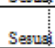 \\
\hline 11 & $\mathrm{MK}$ & 0.49737 & Campak & 0.002631 & Influenza & 0.012631 & \\
\hline 12 & MA & 0.26617 & Difteri & 0.0061713 & Parotitis & 0.053829 & asua \\
\hline 13 & $\mathrm{NA}$ & 0.26598 & Difteri & 0.0059751 & Parotitis & 0.054025 & Tidal: \\
\hline 14 & SJ & 0.28158 & Difteri & 0.021581 & Parotitis & 0.038419 & suge \\
\hline 15 & GD & 0.31938 & Parotitis & 0.00061613 & Difteri & 0.059384 & \\
\hline 16 & $\overline{\mathrm{IM}}$ & 0.56174 & Faringitis & 0.0017437 & DBD & 0.028256 & Sesua \\
\hline 17 & MFA & 0.50513 & Influenza & 0.0048693 & Campak & 0.0051307 & Tidals \\
\hline 18 & ML & 0.56019 & Faringitis & 0.00018963 & DBD & 0.02981 & Sesus \\
\hline 19 & SL & 0.50162 & Campak & 0.0016152 & Influenza & 0.0083848 & Sesua \\
\hline 20 & $\overline{V L}$ & 0.56019 & Faringitis & 0.00018963 & DBD & 0.02981 & Seas \\
\hline
\end{tabular}

Gambar 9. Hasil Pengujian JST

Hasil pengujian merupakan tingkat kesalahan aplikasi menditeksi penyakit, sehingga dari hasil 20 pasien rekam medik tersebut dapat menunjukan aplikasi memiliki tingkat keakuratan mendiagnosa penyakit demam dini pada balita sebesar $86.67 \%$.

\section{Kesimpulan}

Berdasarkan hasil penelitian dan analisa hasil penelitian, dapat diambil beberapa kesimpulan diantaranya aplikasi ini mampu mengenali diagnosa penyakit dengan menggunakan 40 data pelatihan dan 20 data pengujian dengan unit input bernilai 40 serta hidden layer bernilai 4 dengan target MSE (0.000017427).

Dari hasil Pengujian bahwa aplikasi ini mampu mendiagnosis sepuluh penyakit dari 20 pasien dengan tingkat akurasi sebesar $86.67 \%$.

\section{Daftar Pustaka}

Abdel, B.M., Salem, B.M., 2003. A Case Based Adaption Model for Tyroid Cancer Diagnosis Using Neural Networks. Aish Shams Universty. Egyp.

Durkin, J., 1994. Expert System Design and Development. New Jersey: Prentice Hall Inc.

Dhany, S., 2009. Perancangan Sistem Pakar Untuk Diagnosa Penyakit Anak. Skripsi, Univ. Sumatra Utara. Medan.
Faris., 2009. Memahami Demam dengan Lebih baik. Website http://klinikkeluargasehat.wordpress.com /2009/03/23/demam/. Diakses tanggal 16 mei 2012.

Giarratano, J.C., Riley, G., 1994. Expert Systems: Princples and Programming, 2nd edition. PWS Publishing Co, USA.

Gauch, S., Smith, J.B., 1993. An Expert System for Automatic Query Reformulation. Department of Computer Science University of North Carolina N00014-86-K-0680.

Handayani, L., Sutikno, T., 2008. Sistem Pakar untuk Diagnosis Penyakit THT berbasis Web dengan e2gLite Expert System Shell. Universitas Ahmad dahlan, Yogjakarta.

Harry, K., Taufik, H., 2008. Perancangan Program Pengenalan Wajah mennggunakan Fungsi Jarak Metode Euclidean pada Matlab. Universitas Islam Indonesia, Yogyakarta.

Hermawan, A., 2006. Jaringan Syaraf Tiruan teori dan aplikasi. Penerbit Andi, Yogyakarta.

Ismoedijanto., 2009. Demam pada Anak. Website :

http://www.idai.or.id/saripediatri/cariisi/viewfulltext. asp?ID=146 . Diakses 6 Maret.

Kusumadewi, S., 2003. Artificial Intelligence (Teknik dan Aplikasinya). Penerbit Graha Ilmu, Yogyakarta.

Krafchik, B.R., 2000. Viral Exanthems. In : Harper, J., Oranje, A., Prose, N. (Eds) Textbook Of Pediatric Dermatology, London : Blackwell Science 2000.h. 329-46.

Ria, A., 2010. Sistem pakar untuk mendiagnosa macam-macam penyakit demam pada anak berbasis web. Skripsi, STIMIK Samarinda.

Sandra., 2005. Aplikasi jaringan syaraf tiruan untuk pendugaan mutu mangga segar secara nondestruktif. Skripsi, Univ. Andalas Medan, Medan.

Setiawan, S., 2003. Perancangan dan pembuatan sistem pakar pada pengobatan penyakit umum dengan tanaman obat pada manusia. Skripsi, Univ. Kristen Petra, Surabaya.

Soebdibyo, S., Souvriyanti, E., 2006. Gambaran persepsi orang tua tentang penggunaan antipriretik sebagai obat demam. Website:http://www.idai.or.id/saripediatri/cariisi/ viewfulltext.asp?ID=434. Diakses : 5 Februari 2012.

Sulistyohati, A., Hidayat, T., 2008. Aplikasi sistem pakar diagnosa penyakit ginjal dengan metode dempster-shafer. Prosiding SNATI.

Turban, Efraim., 1995. Decision Support and Expert Systems Management Support Systems (fourth edition). Prentice-Hall International, Inc. 